\title{
Cell Wall Analysis of Oral Filamentous Bacteria
}

\author{
By R. BABOOLAL* \\ Department of Dental Bacteriology and Biochemistry, \\ The London Hospital Medical College, Turner Street, London, E.I
}

(Accepted for publication 13 June 1969)

\begin{abstract}
SUMMAR Y
The cell wall compositions of 4 I strains of oral filamentous bacteria belonging to the genera Fusobacterium, Leptotrichia and Bacterionema were examined by paper chromatography. Leptotrichia walls showed principally alanine, glutamic acid, DAP, glycine and aspartic acid. The genus Bacterionema had the same amino acids but aspartic acid appeared to be a minor component and was not detected in the mucopeptide fraction of the cell walls. The strains of Fusobacterium gave an amino acid pattern characteristic of Gram-negative bacteria; however, lysine was a major component in the mucopeptide. The genus Leptotrichia is thus distinct from the other two genera and should include two species, Leptotrichia buccalis and another organism termed 'Anaerobic filaments'.
\end{abstract}

\section{NTRODUCTION}

The human oral cavity supports the growth of a wide variety of micro-organisms including several different Gram-positive filamentous types, some of which are often classified in the genus Leptotrichia. Members of this genus are primarily oral inhabitants which are micro-aerophilic or anaerobic. Despite numerous investigations (Thjøtta, Hartman \& Bøe, I939; Baird-Parker, I959; Theilade \& Gilmour, 196I; Sibal, Kroeger, Kumarich \& Meyer, I962; Hofstad, I967a), there is still much confusion concerning the nomenclature and classification of these micro-organisms. For example, the name Leptotrichia buccalis has been used synonymously for two completely different oral bacteria and it appears that the type species of the genus Fusobacterium, F. fusiforme, is synonymous with L. buccalis (Jackins \& Barker, I95I). Recent reports (Theilade \& Gilmour, 196I; Kasai, 1965; Hofstad, 1967a) have indicated that there are other filamentous bacteria which may or may not be related to members of the genus Leptotrichia.

In the present study the cell wall compositions of $4 \mathrm{I}$ strains of oral filamentous bacteria was examined by paper chromatography with the hope that the information might be of some taxonomic value in the classification of these micro-organisms.

\section{METHODS}

Organisms. The strains used and their sources are listed in Table I. The method employed for isolating and characterizing fresh isolates has been previously described

* Present address: University College Hospital Medical College Dental Hospital, Department of Biochemistry, Mortimer Market, London, W.C. I. 
(Baboolal, I968). Unless otherwise stated Bacterionema matruchotii strains were grown aerobically, while strains of Leptotrichia buccalis, Fusobacterium nucleatum and the 'Anaerobic filaments' were grown anaerobically in McIntosh and Fildes jars in an atmosphere containing $10 \%(\mathrm{v} / \mathrm{v}) \mathrm{CO}_{2}$ in $\mathrm{N}_{2}$.

Table I. Source of strains used in this study

\begin{tabular}{|c|c|c|}
\hline Micro-organism & Laboratory designatior & Source \\
\hline Leptotrichia buccalis & 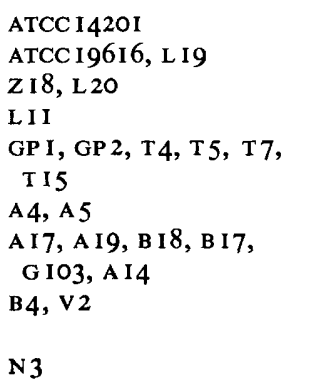 & $\begin{array}{l}\text { American Type Culture Collection } \\
\text { M. Gilmour, Rochester, New York } \\
\text { G. J. Kasai, Chicago } \\
\text { Tor Hofstad, Bergen, Norway } \\
\text { G. L. Slack \& G. H. Bowden, isolated } \\
\text { from experimental plaque } \\
\text { Chronic marginal gingivitis } \\
\text { Dental plaque } \\
\text { Acute ulcerative gingivitis (Vincent's } \\
\text { disease) } \\
\text { Carious lesion }\end{array}$ \\
\hline 'Anaerobic filaments' & $\begin{array}{l}\text { L } 2 \text { I, L } 44, \mathrm{~L} 52 \\
\mathrm{CWI} \\
\text { T2 } \\
\text { TI2, T } 19\end{array}$ & $\begin{array}{l}\text { Tor Hofstad, Bergen, Norway } \\
\text { E. Theilade, Denmark } \\
\text { G. L. Slack \& G. H. Bowden, isolated } \\
\text { from experimental plaque } \\
\text { Dental plaque }\end{array}$ \\
\hline Bacterionema matruchotii & $\begin{array}{l}\text { ATCC I } 4266 \\
\text { NCTC I0206 } \\
\text { I } 8,207 \\
\text { G I } 32 \\
\text { LD I }\end{array}$ & $\begin{array}{l}\text { American Type Culture Collection } \\
\text { National Collection of Type Cultures } \\
\text { M. Gilmour, Rochester, New York } \\
\text { G. J. Kasai, Chicago } \\
\text { Dental plaque }\end{array}$ \\
\hline Fusobacterium nucleatum & $\begin{array}{l}\mathrm{VI}, \mathrm{F} \text { I } \\
\mathrm{C} 3, \mathrm{~F} 2, \mathrm{~F} 3\end{array}$ & $\begin{array}{l}\text { Acute ulcerative gingivitis (Vincent's } \\
\text { disease) } \\
\text { Dental plaque }\end{array}$ \\
\hline
\end{tabular}

Biochemical tests. The basal medium for carbohydrate fermentation and other physiological tests was that of Kasai (1965). The sugars (10 \% w/v, sterilized by filtration) were added to the basal medium (previously sterilized) to I \% . Nitrate, gelatin and starch were added to the basal medium to $0 \cdot \mathrm{I}, \mathrm{I} 2$ and $2 \% \mathrm{w} / \mathrm{v}$ respectively. The various tests were inoculated with a culture prepared from single colonies selected from blood agar and grown in Medium B (below) for 24 or $48 \mathrm{hr}$. Since $\mathrm{CO}_{2}$ lowers the $\mathrm{pH}$ of test substances in the anaerobic jars, uninoculated controls were included and the results were read relative to the controls. Tests were conducted according to the procedures outlined in the Manual of Microbiological Methods (I957) $\mathrm{H}_{2} \mathrm{~S}$ production was detected with lead acetate paper strips.

Medium B contained $(\%, \mathrm{w} / \mathrm{v})$ : Proteose peptone (Oxoid) $\mathrm{I} \cdot \mathrm{O}$; Yeast extract (Oxoid) 0.I; 'Lab Lemco' beef extract (Oxoid) 0.3; Soluble starch 0.2; $\mathrm{Na}_{2} \mathrm{HPO}_{4}$. $\mathrm{I}_{2} \mathrm{H}_{2} \mathrm{O} 0.5$; Sodium nitrate $0 . \mathrm{I}$; L-Cysteine $\mathrm{HCl} 0.05$; Sodium bicarbonate $0 . \mathrm{I}$; the $\mathrm{pH}$ value was $7 \cdot 6$.

Preparations of cell walls. One 1 . medium B was dispensed in a $\mathrm{I} \cdot 51$. flask and $50 \mathrm{ml}$. liquid paraffin were added to provide semi-anaerobic conditions. The facultative strains of Bacterionema matruchotii were grown aerobically in the same medium for $72 \mathrm{hr}$. at $37^{\circ}$. Cultures were harvested by centrifugation and the cells were heated at $75^{\circ}$ for $5 \mathrm{~min}$., washed once in distilled water and twice in physiological saline. The 
washed cells were resuspended in $8 \mathrm{ml}$. of distilled water, one drop of iso-octanol added and the suspension shaken in a Mickle Tissue Disintegrator at room temperature with an equal volume of ballotini glass beads (Jencon's Grade 12). Disruption was considered complete when no intact organism could be seen in Gram-stained smears. The disintegrated cells were separated from the glass beads, centrifuged Io min. at $2000 \mathrm{~g}$ to remove any unbroken cells and the supernatant centrifuged $30 \mathrm{~min}$. at $20,000 \mathrm{~g}$ to deposit the cell walls. The pellet was washed twice with molar saline, resuspended in $6 \mathrm{ml}$. $/ \mathrm{I} 5$ phosphate buffer, $\mathrm{pH} 8$, containing I mg. $/ \mathrm{ml}$. crystalline trypsin, incubated $6 \mathrm{hr}$. at $37^{\circ}$ and centrifuged $30 \mathrm{~min}$. at $20,000 \mathrm{~g}$. The trypsinized cell walls were washed several times in distilled water and finally freezedried. A few cell-wall preparations were checked for purity by electron microscopy.

Preparation of mucopeptide from cell walls. The method employed was essentially similar to that described by Perkins (1965). Freeze-dried cell walls (100 mg.) was extracted with $15 \mathrm{ml}$. formamide at $160^{\circ}$ with constant stirring in an bath. The mixture was cooled and $30 \mathrm{ml}$. acid ethanol were added. The residue was recovered by centrifugation, washed with acid alcohol, ethanol, ether and twice with distilled water. After drying in vacuo over $\mathrm{P}_{2} \mathrm{O}_{5}$ the residue was weighed. The experiment was repeated three times and the proportion of mucopeptide (from the weight of the final residue) in the various cell wall preparations are included in Table 5. The supernatant was treated with 5 vol. acetone and stood I hr at room temperature. The white precipitate was redissolved in distilled water, reprecipitated with acetone and further purified by repeated dialysis against distilled water. The quantity of material recovered from the supernatant varied considerably owing to loss during the purification stages. In a typical experiment employing $100 \mathrm{mg}$. of Leptotrichia buccalis cell wall $40 \mathrm{mg}$. was recovered as mucopeptide and $30 \mathrm{mg}$. from acetone precipitation of the supernatant.

Lipid estimation. Ether extractable material from cell walls was estimated by a modification of Salton's method (I953). Cell walls were suspended in $2 \mathrm{~N}-\mathrm{HCl}$, treated $2 \mathrm{hr}$ at $100^{\circ}$ and extracted with ether continuously for 5 days. The ether was removed by evacuation and the residue redissolved in ether. The latter procedure was repeated twice and the final residue was evacuated to dryness before weighing.

Hydrolysis of cell wall mucopeptide and polysaccharide. Hydrolysates for detection of reducing sugars were prepared by heating samples $2 \mathrm{hr}$ with $2 \mathrm{~N}-\mathrm{HCl}$ in sealed tubes at $100^{\circ}$. They were filtered and the $\mathrm{HCl}$ removed by evacuating to dryness in vacuo over $\mathrm{P}_{2} \mathrm{O}_{5}$. For amino acids and hexosamines, samples were hydrolysed $20 \mathrm{hr}$ with $6 \mathrm{~N}-\mathrm{HCl}$ at $100^{\circ}$ and the excess $\mathrm{HCl}$ removed as described previously. The final residues were redissolved in $10 \%$ isopropanol and stored at $4^{\circ}$.

Chromatography. Amino acids were repeated on two dimensional ascending chromatograms of Whatman No. $110 \times 10$ in., filter paper irrigated $18 \mathrm{hr}$ each with ethanol $+n$-butanol + water + propionic acid $(10+10+5+2 \mathrm{v} / \mathrm{v})$ and, after drying, with $n$-butanol + acetone + water + dicyclohexylamine $(10+10+5+5 \mathrm{v} / \mathrm{v})$ as described by Hardy, Holland \& Naylor (1955), before developing. The amount of cell walls subjected to chromatography was equivalent to I $\mathrm{mg}$. dry weight. Separation of DD-or DLand LL-diaminopimelic acid (DAP) was similar in all essential details to the method described by Hoare \& Work (I957); since the DL- and DD- isomers cannot be separated by paper chromatography the results are recorded as DL-DAP or LL-DAP.

Reducing sugars were separated on Whatman No. I filter paper irrigated $20 \mathrm{hr}$ with $n$-butanol + pyridine + water $(6+4+3 \mathrm{v} / \mathrm{v})$ (Jeanes, Wine \& Dunbar, I95I). Amino 
sugars were separated by one dimensional descending chromatography on Whatman No.I paper, previously treated with 0.I $\mathrm{M}-\mathrm{BaCl}_{2}$ (Heyworth, Perkins \& Walker, I96I) and irrigated $36 \mathrm{hr}$ in the solvent system used for reducing sugars.

Detection of components. Amino acid chromatograms were dried, sprayed with $0.25 \%$ ninhydrin in acetone plus $7 \%$ glacial acetic acid and heated about $5 \mathrm{~min}$. at $75^{\circ}$. The identity of some spots was confirmed by ionophoresis. Reducing sugars were detected with aniline hydrogen phthalate (Partridge, 1949) and their identity confirmed by running standard mixtures on the chromatograms. Amino sugars were detected by the Elson-Morgan reaction as modified by Partridge \& Westall (I948).

\section{RESULTS}

The micro-organisms were characterized by their colonial and cellular morphology and the tests shown in Table 2. Strains of Leptotrichia buccalis and the 'Anaerobic filaments' showed some similarity in a number of tests. Both groups were saccharolytic, failed to produce catalase, $\mathrm{H}_{2} \mathrm{~S}$ and reduce nitrate. Some variation was found with respect to carbohydrate fermentation among strains of $L$. buccalis, but a number of other investigators (Kasai, I965; Takazoe \& Frostell, 1960; Hamilton \& Zahler, 1957) have reported similar observations.

Cell wall analyses of the various groups of filamentous bacteria examined are shown in Table 3. The twenty-three strains of Leptotrichia buccalis gave identical cellwall patterns with respect to their amino acids, amino sugars and reducing sugars. A slow running component which gave a weak positive Elson-Morgan reaction was detected in most hydrolysates; it ran slower than muramic acid in the solvent system used. Glucose was the principal reducing sugar with galactose as a minor component. The principal amino sugars were muramic acid and glucosamine, but galactosamine was also detected in all the strains examined. The major amino acids were alanine, glutamic acid, DAP, aspartic acid, and glycine, with valine as a minor component. Serine, lysine, ornithine and leucine were detected in trace amounts. The occurrence of aspartic acid as a major component in the cell walls of $L$. buccalis and the 'Anaerobic filaments' indicated that this substance might be associated with the mucopeptide. Preliminary experiments, using cell walls extracted with $0.5 \% \mathrm{KOH}$ in ethanol (Cummins \& Harris, I958) gave a cell-wall pattern of amino acids similar to that of non-extracted walls, with aspartic acid as a major component. However, if cell walls were extracted with formamide and the insoluble residue analysed, aspartic acid was detected (Table 5). It appears that the mucopeptide fractions of the cell walls of $L$. buccalis and the 'Anaerobic filaments' contained alanine, glutamic acid, DAP, glycine and aspartic acid. L. buccalis and the 'Anaerobic filaments' then had similar amino acids in their wall and mucopeptide, and similar proportions of mucopeptide in the cell walls. However, the reducing sugar patterns were different in that the walls of $L$. buccalis had glucose and galactose while the 'Anaerobic filaments' contained glucose and rhamnose.

The principal amino acids of the cell walls of Bacterionema matruchotii were in general similar to those of Leptotrichia buccalis, but aspartic acid appeared to be a minor component, and the absence of this amino acid in the mucopeptide was considered significant (Table 5). Arabinose was a major component in the walls of B. matruchotii; this sugar is commonly found among members of the genera Corynebacterium, Nocardia and Mycobacterium (Cummins, 1962). 


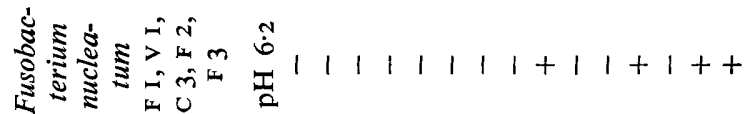

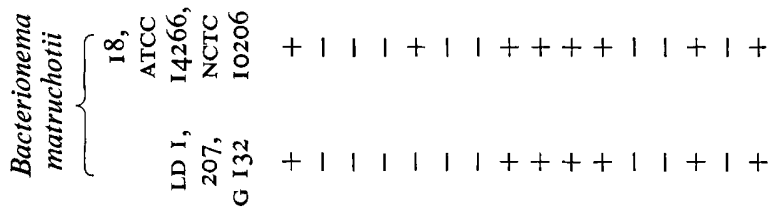

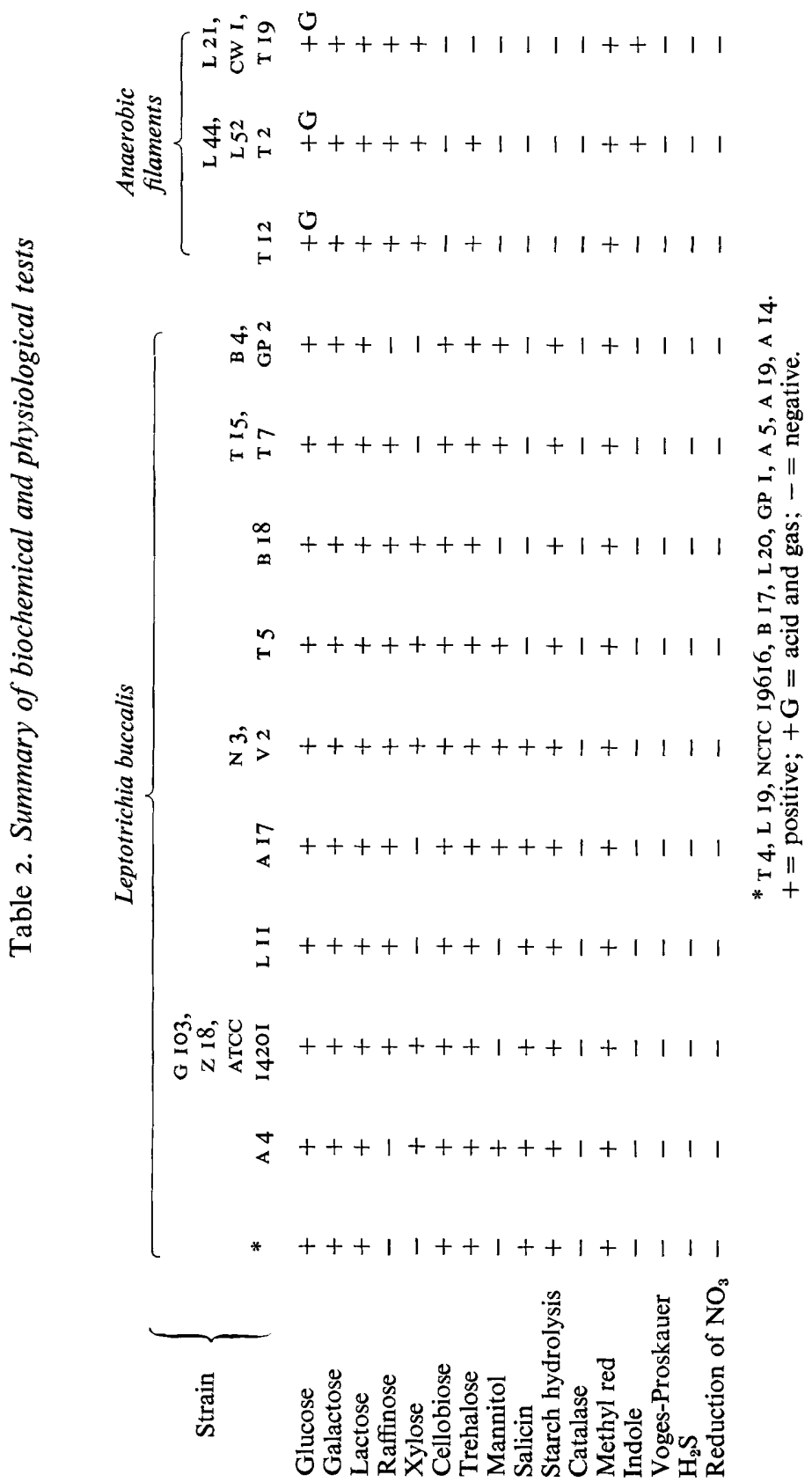


Table 3. Cell-wall composition results in strains of Leptotrichia buccalis and other filamentous types

\begin{tabular}{|c|c|c|c|c|}
\hline & $\begin{array}{l}\text { L. buccalis } \\
23 \text { strains }\end{array}$ & $\begin{array}{l}\text { 'Anaerobic } \\
\text { filaments' } \\
7 \text { strains }\end{array}$ & $\begin{array}{c}\text { Bacterionema } \\
\text { matruchotii } \\
6 \text { strains }\end{array}$ & $\begin{array}{c}\text { Fusobacteriur } \\
\text { nucleatum } \\
5 \text { strains }\end{array}$ \\
\hline $\begin{array}{l}\text { Glucose } \\
\text { Galactose } \\
\text { Arabinose } \\
\text { Rhamnose }\end{array}$ & $\begin{array}{c}++ \\
+ \\
- \\
-\end{array}$ & $\begin{array}{c}++ \\
- \\
+ \\
+\end{array}$ & $\begin{array}{c}++ \\
+ \\
+++ \\
+\end{array}$ & $\begin{array}{c}+++ \\
++ \\
- \\
-\end{array}$ \\
\hline $\begin{array}{l}\text { Glucosamine } \\
\text { Galactosamine } \\
\text { Muramic acid }\end{array}$ & $\begin{array}{c}+++ \\
+ \\
++\end{array}$ & $\begin{array}{c}++ \\
+ \\
++\end{array}$ & $\begin{array}{c}+++ \\
+ \\
++\end{array}$ & $\begin{array}{c}+++ \\
+ \\
+\end{array}$ \\
\hline $\begin{array}{l}\text { LL-Diamino- } \\
\text { pimelic acid }\end{array}$ & - & - & - & - \\
\hline $\begin{array}{l}\text { DL-Diamino- } \\
\text { pimelic acid }\end{array}$ & +++ & +++ & +++ & - \\
\hline Alanine & +++ & +++ & +++ & +++ \\
\hline $\begin{array}{l}\text { Glutamic acid } \\
\text { Aspartic acid }\end{array}$ & $\begin{array}{l}+++ \\
+++\end{array}$ & $\begin{array}{l}+++ \\
+++\end{array}$ & $\begin{array}{c}++ \\
+\end{array}$ & $\begin{array}{c}+++ \\
++\end{array}$ \\
\hline Glycine & ++ & ++ & ++ & +++ \\
\hline Ornithine & $\operatorname{tr}$ & $\operatorname{tr}$ & - & ++ \\
\hline Leucine & tr & $\operatorname{tr}$ & tr & + \\
\hline Valine & + & + & $\operatorname{tr}$ & ++ \\
\hline Serine & $\operatorname{tr}$ & $\operatorname{tr}$ & - & + \\
\hline Cysteine & - & - & - & + \\
\hline Lysine & $\operatorname{tr}$ & $\operatorname{tr}$ & $\operatorname{tr}$ & +++ \\
\hline
\end{tabular}

+++ , Major component; + , minor component; - , not detected; ++ , moderate amount; tr, trace amount.

Table 4. Comparative patterns of the principal cell-wall components of certain groups of bacteria

\begin{tabular}{|c|c|c|c|c|c|}
\hline & $\begin{array}{l}\text { Leptotrichia } \\
\text { buccalis }\end{array}$ & $\begin{array}{l}\text { Anaerobic } \\
\text { filaments }\end{array}$ & $\begin{array}{c}\text { Bacterionema } \\
\text { matruchotii }\end{array}$ & $\begin{array}{c}\text { Actinomyces } \\
\text { israelii* }\end{array}$ & $\begin{array}{l}\text { Nocardia } \\
\text { asteroides* }\end{array}$ \\
\hline Arabinose & - & - & $+t+$ & - & $+t+$ \\
\hline Galactose & + & - & + & ++ & ++ \\
\hline Glucose & +++ & +++ & $++t$ & - & + \\
\hline Rhamnose & - & ++ & - & - & - \\
\hline Muramic acid & ++ & ++ & ++ & + & + \\
\hline Glucosamine & +++ & +++ & $+t+$ & + & + \\
\hline Galactosamine & + & + & + & - & - \\
\hline Alanine & +++ & +++ & $+t+$ & +++ & $++t$ \\
\hline Glutamic acid & +++ & $++t$ & +++ & +++ & +++ \\
\hline \multicolumn{6}{|c|}{ Diaminopimelic acid } \\
\hline DL & +++ & $+t+$ & $++t$ & - & $++t$ \\
\hline LL & - & - & - & - & - \\
\hline Lysine & - & - & - & +++ & - \\
\hline Glycine & ++ & ++ & ++ & - & - \\
\hline Aspartic acid & +++ & +++ & $\dagger$ & - & - \\
\hline
\end{tabular}

* Data taken from Cummins (I962).

$\uparrow$ Not detected in mucopeptide fraction of the cell walls. 
The Fusobacterium strains gave amino acid patterns which were considered typical of Gram-negative bacteria and the small amount of mucopeptide present in their cell walls substantiated this conclusion. Muramic acid and glucosamine were detected in all mucopeptide preparations and analysis of the polysaccharide material obtained by formamide extraction suggested that the galactosamine detected in cell-wall hydrolysates of Leptotrichia buccalis, Bacterionema matruchotii and the 'Anaerobic filaments' is perhaps associated with the polysaccharide (Table 6).

Table 5. The quantitative analyses of lipid and mucopeptide from cell walls and the components detected in the mucopeptide fraction

\begin{tabular}{|c|c|c|c|c|}
\hline & $\begin{array}{l}\text { Leptotrichia } \\
\text { buccalis }\end{array}$ & $\begin{array}{l}\text { Anaerobic } \\
\text { filaments }\end{array}$ & $\begin{array}{c}\text { Bacterionema } \\
\text { matruchotii }\end{array}$ & $\begin{array}{l}\text { Fusobacterium } \\
\text { nucleatum }\end{array}$ \\
\hline Mucopeptide (\%) & 40 & 43 & 58 & 6 \\
\hline Lipid $(\%)$ & 12 & IO & I. 5 & 20 \\
\hline Alanine & +++ & +++ & +++ & +++ \\
\hline Glutamic acid & +++ & +++ & +++ & $++t$ \\
\hline $\begin{array}{l}\text { Diaminopimelic } \\
\text { acid }\end{array}$ & +++ & +++ & +++ & - \\
\hline Glycine & ++ & ++ & ++ & + \\
\hline Aspartic acid & ++ & ++ & - & - \\
\hline Lysine & - & - & - & ++ \\
\hline Muramic acid & ++ & ++ & ++ & ++ \\
\hline Glucosamine & +++ & +++ & +++ & +++ \\
\hline Galactosame & - & - & - & - \\
\hline
\end{tabular}

Table 6. Qualitative analyses of cell-wall polysaccharides

\begin{tabular}{lccc} 
Leptotrichia & $\begin{array}{c}\text { Anaerobic } \\
\text { buccalis }\end{array}$ & $\begin{array}{c}\text { Bacterionema } \\
\text { matruchotii }\end{array}$ \\
Glucose & + & + & + \\
Galactose & + & - & + \\
Arabinose & - & - & + \\
Rhamnose & - & + & + \\
Galactosamine & + & + & + \\
\multicolumn{4}{c}{ +, Detected; - , not detected. }
\end{tabular}

The amounts of lipid (ether extractable material) in the walls of Leptotrichia buccalis and the 'Anaerobic filaments' (Io to $12 \%$ of the weight of the walls, Table 5) were much lower than that of Fusobacterium nucleatum but considerably higher than that of Bacterionema matruchotii ( $1 \cdot 5 \%$. Walls of $L$. buccalis and the 'Anaerobic filaments' apparently contain substantial amounts of lipid.

\section{DISCUSSION}

Chemical analysis of bacterial cell walls appears to be a useful taxonomic tool; Cummins \& Harris (1956) suggested that the pattern of amino acids of the cell walls characterizes the various genera, or taxa higher than species, and that the nature of the sugars characterizes species. The 23 strains of Leptotrichia buccalis examined form a homogenous group in their cell-wall patterns and no differences were found between strains isolated from Vincent's infection and those obtained from other sources. 
The results recorded in Tables 3 and 5 show that Leptotrichia buccalis and the 'Anaerobic filaments' have the same amino acids in their cell walls and mucopeptide. From the taxonomic point of view this would indicate that they are probably related if cell-wall composition can be taken as a suitable criterion. Serological data (Baboolal, 1968; Hofstad, 1967a) suggest that there is no relationship between these two groups of micro-organisms and other taxonomic characteristics such as biochemical and phhysiological studies (Table 2, Hofstad, $1967 a$ ) tend to support the results of serological studies.

The taxonomic conclusions drawn from cell-wall analysis and serological studies appear contradictory. This, however, is not surprising since the major cell-wall antigens of these two groups of micro-organisms are two chemically different polysaccharides (Baboolal, I969). Kasai (1965) and Takazoe \& Frostell (1960) have described filamentous types of leptotrichia which the present author believes might be 'Anaerobic filaments'. The cellular and colonial morphology of the 'Anaerobic filaments' and some of their biochemical and physiological properties such as absence of catalase and sensitivity to oxygen would indicate that they are probably related to Leptotrichia.

The results presented in Table 3 differ from those of Hofstad (1967b) and Davis \& Baird-Parker (1959) in that aspartic acid was found as a major component in the cell walls and mucopeptide of Leptotrichia buccalis and the 'Anaerobic filaments'. The latter authors used a one dimensional system and the former employed circular paper chromatography, so the difference in the results presented here might be due to the techniques employed.

The amounts of lipid found in the cell walls of these organisms appear to be relatively high for Gram-positive bacteria, but by no means exceptional, since higher quantities have been found in Corynebacterium diphtheriae (Salton, I964). The isolation of lipopolysaccharide from whole cells of Leptotrichia buccalis (Gustafson, Kroeger, Gustafson \& Vaichulis, I966) and the detection of heptoses (Hofstad, $1967 b$ ) in the walls of the 'Anaerobic filaments' suggest that these organisms have an unusual and complicated cell wall atypical of Gram-positive bacteria, since aldoheptoses have so far been demonstrated only in Gram-positive bacteria. However, the presence of large amounts of mucopeptide (Table 5) and the detection of few amino acids after trypsinization of cell walls are characteristic of Gram-positive bacteria (Salton, I964). The presence of lipopolysaccharide reported in the cell walls of these organisms is an interesting finding and it has also been implicated as a component in the walls of Clostridium welchii (Pickering, 1967).

The absence of aspartic acid in the mucopeptide fraction of Bacterionema matruchotii and its presence in similar preparations of Leptotrichia buccalis and the 'Anerobic filaments' indicates that this difference might be of some taxonomic value. The cell-wall components of $B$. matruchottii suggest that it is perhaps related to Nocardia because of the presence of arabinose as a major sugar. Schmidt \& Richardson (I96I) found that antisera against $B$. matruchotii cross-reacted in complement fixation test with organisms of the genera Mycobacterium, Nocardia, Actinomyces and Corynebacterium and vice versa. However, the amino acid pattern is different from that reported for these genera by Cummins (I962) (Table 4) and its inclusion in a separate genus in the family Actinomycetaceae as proposed by Gilmour, Howell \& Bibby (I96I) is supported by the results of cell-wall studies. 
Old cultures of Leptotrichia buccalis appear 'fusiform'-like and Gram-negative with Gram-positive granules in the cytoplasm. These characters seem to have resulted in the inclusion of this organism in the genus Fusobacterium under the name F. fusiforme which is the type species of this genus. The description of $F$. fusiforme given in the 7 th edition of Bergey's Manual corresponds closely to the descriptions reported for L. buccalis by many investigators. F. fusiforme has been shown to be invalid (BairdParker, 1959) on the grounds that it corresponds to a previously described organism L. buccalis (Trevisan). It appears, therefore, that although the genus Leptotrichia is omitted from the $7^{\text {th }}$ edition of Bergey's Manual, the type species of this genus is classified as the type species of the genus Fusobacterium under the name F. fusiforme. The cell-wall analysis data presented clearly indicate that the genus Fusobacterium have cell walls characteristic of Gram-negative organisms and are distinct from Leptotrichia species. It is interesting to note that lysine is a major component in the mucopeptide fractions of Fusobacterium as this amino acid is not usually found in such preparations from Gram-negative organisms.

I wish to thank Professor G. L. Slack for the laboratory facilities placed at my disposal and Professor C. S. Cummins for his helpful suggestions. The technical assistance of $\mathrm{Mr} \mathrm{K}$. Hutchins is greatly appreciated.

\section{REFERENCES}

Baboolal, R. (1968). A study of Leptotrichia buccalis. Ph.D. thesis. University of London.

Baboolal, R. (1969). Cell wall composition and antigenic structure of the genus Leptotrichia. J. dent. Res. abst. (In the Press.)

BaIrd-PARker, A. C. (1959). The classification of oral Leptotrichia and Fusobacterium species. Ph.D. thesis. University of Birmingham.

Bergey's Manual of Determinative Bacteriology (1957). 7th ed. Ed. by R. S. Breed, E. G. D. Murray and N. R. Smith. London: Baillière, Tindall and Cox.

Cummins, C. S. (1962). Chemical composition and antigenic structure of cell walls of Corynebacterium, Mycobacterium, Nocardia, Actinomyces and Arthrobacter. J. gen. Microbiol. 28, 35.

Cummins, C. S. \& Harris, H. (1956). The chemical composition of the cell wall in some Grampositive bacteria and its possible value as a taxonomic character. J. gen. Microbiol. $\mathbf{1}_{4}, 583$.

Cummins, C. S. \& Harris, H. (1958). Studies on the cell-wall composition and taxonomy of Actinomycetales and related groups. J. gen. Microbiol. $18,173$.

Davis, G. H. G. \& Baird-Parker, A. C. (I959). The classification of certain filamentous bacteria with respect to their chemical composition. J. gen. Microbiol. 2I, 6I 2.

Gilmour, M. N., Howell, A. Jun. \& BibBY, B. G. (I96I). The classification of organisms termed Leptotrichia (Leptothrix) buccalis. I. Review of literature and proposed separation into Leptotrichia buccalis (Trevisan 1879) and Bacterionema, gen. nov. B. matruchotii (Mendel, 1919) Comb. nov. Bact. Rev. 25, I3I.

Gustafson, R. L., Kroeger, A. V., Gustafson, J. L. \& Vaichulis, E. M. K. (I966). The biological activity of Leptotrichia buccalis endotoxin. Arch. oral Biol. II, 1149.

Hamilton, R. D. \& Zahler, S. A. (I957). A study of Leptotrichia buccalis. J. Bact. 73, 386.

Hardy, T. L., Holland, D. O. \& NAYLOR, J. H. C. (1955). One phase solvent mixture for the separation of amino acids. Analyt. Chem. 27, 97 I.

Heyworth, R., Perkins, H. R. \& Walker, P. G. (I96I). Paper chromatography of hexosamines and $N$-acetyl hexosamines. Nature, Lond. rgo, $26 \mathrm{I}$.

HoAre, D. S. \& Work, E. (1957). The sterioisomers of $\alpha$-diaminopimelic acid. II. Their distribution in the bacterial order Actinomycetales and in certain Eubacteriales. Biochem. J. 65, 44I.

HoFsTAD, T. (1967a). An anaerobic oral filamentous organism possibly related to Leptotrichia buccalis. I. Morphology, some physiological and serological properties. Acta path. microbiol. scand. 69, 543. 
HoFsTAD, T. (1967b). An anaerobic oral filamentous organism possibly related to Leptotrichia buccalis.

II. Composition of cell walls. Acta path. microbiol. scand. 70, 46I.

JACKINS, H. C. \& BARKER, H. A. (I95I). Fermentative processes of the fusiform bacteria. J. Bact. 6r, IOI.

JEANES, A., Wine, C. S. \& DUNBAR, R. S. (195I). Improved techniques in paper chromatography of carbohydrates. Analyt. Chem. 23, 415.

KASAI, G. J. (1965). A study of Leptotrichia buccalis. II. Biochemical and physiological observations. J. dent. Res. 44, Ior 5 .

Manual of Microbiological Methods by the Society of American Bacteriologist. (1957). New York, Toronto, London: McGraw-Hill Co.

Patridge, S. M. (1949). Aniline phthalate spray reagent for the detection of reducing sugars. Nature, Lond. 164, 443.

Patridge, S. M. \& Westall, R. G. (1948). Filter paper partition chromatography. Biochem. J. 42, 238.

Perkins, H. R. (1965). The action of hot formamide on bacterial cell walls. Biochem. J. 95, 876.

PICKERING, B. T. (I967). Components of the cell wall of Clostridium welchii type (A). Biochem. J. I00, 430 .

SALton, M. R. J. (1953). Studies of the bacterial cell wall. IV. The composition of the cell walls of some Gram-positive and Gram-negative bacteria. Biochim. biophys. Acta ro, 52.

Salton, M. R. J. (1964). The Bacterial Cell Wall. Amsterdam, London, New York: Elsevier Pub. Co.

SCHMIDT, J. M. \& RICHARDSON, R. L. (I96I). Antigenic relationship of an oral filamentous organism. Bact. Proc. p. 74.

Sibal, R. L., Kroeger, A. V., Kumarich, D. \& MeYer, E. (I962). Serological specificity of acidsoluble antigens of Bacterionema matruchotii. J. Bact. 83, 8I I.

TAKAZOE, I. \& Frostell, E. (1960). A study of some properties of Leptotrichia. Acta odont. scand. 18,365 .

Theilade, E. \& GILMOUR, M. N. (196I). An anaerobic oral filamentous micro-organism. J. Bact. 8I, $66 \mathrm{I}$.

Thjøtta, T., Hartman, O. \& BøE, J. (1939). The study of Leptotrichia (Trevisan) Skr.norske, Videnscap-Acad. Mat-naturv. Kl. no. 5. 